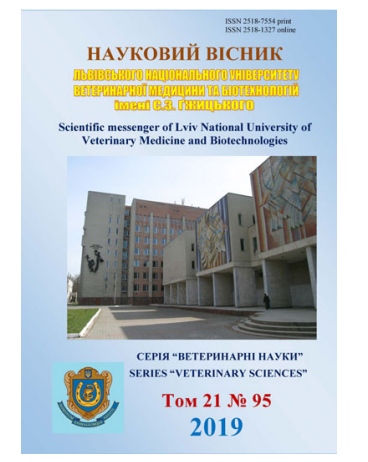

Науковий вісник Дьвівського національного університету ветеринарної медицини та біотехнологій імені С.3. Гжицького. Серія: Ветеринарні науки

Scientific Messenger of Lviv National University of Veterinary Medicine and Biotechnologies. Series: Veterinary sciences

\title{
Determination of bactericidal properties of the drug "Saroflox" in relation to museum test cultures of microorganisms
}

\author{
A.M. Golovko ${ }^{1}$, N.G. Pinchuk ${ }^{1}$, T.I. Fotina ${ }^{2}$, Zh.E. Klishchova ${ }^{2}$ \\ ${ }^{1}$ State Scientific Control Institute of Biotechnology and Microorganism, Kyiv, Ukraine \\ ${ }^{2}$ Sumy National Agrarian University, Sumy, Ukraine
}

\section{Article info}

Received 11.09.2019

Received in revised form 14.10.2019

Accepted 15.10.2019

State Scientific Control Institute of Biotechnology and Microorganism, Donetska, Str., 30, Kyiv, 03151, Ukraine.

Sumy National Agrarian University, G. Kondratieva Str., 160, Sumy, 40021, Ukraine. Tel.: +38-095-572-24-98 E-mail:kgejp1990@gmail.com
Golovko, A.M., Pinchuk, N.G., Fotina, T.I., Klishchova, Zh.E. (2019). Determination of bactericidal properties of the drug "Saroflox" in relation to museum test cultures of microorganisms. Scientific Messenger of Lviv National University of Veterinary Medicine and Biotechnologies. Series: Veterinary sciences, 21(95), 89-92. doi: 10.32718/nvlvet9516

Everyone knows that test cultures are used to control and quality the growth properties of nutrient media, to check the activity of antiseptics and disinfectants, as well as to assess the adequacy of the sensitivity of the tested microorganisms to new antibacterial drugs, which are currently produced by rapid temp. with the development of antibiotic resistance of microorganisms to most of the active substances used in new drugs. Moreover, it is the understanding that most antibiotics are clinically useless in treating infectious diseases because of their long-term use for chemotherapy purposes - a major problem not only in Ukraine but worldwide. In this article the results of researches sensitivity museum strains, namely: Escherichia coli ATCC 25922 (F-50), Pseudomonas aeruginosa ATCC 2853 (F), Proteus vulgaris HX 19 number 222, Staphylococcus aureus ATCC 25923, Enterobacter aerogenes 10006, Enterococcus faecalis ATCC 19433 to the antibacterial drug "Saroflox". We find that Saroflox inhibited the growth of all test cultures at different dilution rates. Using different concentrations of the antibiotic $(2.5 \mathrm{mg}, 1.25 \mathrm{mg}, 0.625 \mathrm{mg}, 0.3125 \mathrm{mg}$, $0.1562 / 200 \mu l$ ), it was found that all test cultures under study were highly sensitive to Saroflox. most from $38.0 \pm 1.0$ to $20.0 \pm 1.0 \mathrm{~mm}$. The results of studies show that the new antibacterial drug "Saroflox" has bactericidal properties to most cultures that cause bacterial diseases of various species of animals and birds, which only confirms its effectiveness against gram-negative microorganisms (Enterobacter spp. , Staphylococcus aureus E. coli and others) including beta-lactam antibiotic resistant, tetracyclines, macrolides and aminoglycosides.

Key words: sensitivity, microorganisms, test cultures, bactericidal, Saroflox drug.

\section{Визначення бактерицидних властивостей препарату “Сарофлокс" щодо музейних тест-культур мікроорганізмів}

\author{
А.М. Головко ${ }^{1}$, Н.Г. Пінчук ${ }^{1}$, Т.І. Фотіна ${ }^{2}$ ж.Є. Кліщова ${ }^{2}$ \\ ${ }^{1}$ Державний науково-контрольний інститут біотехнології і штамів мікроорганізмів, м. Київ, Україна \\ ${ }^{2}$ Сумський наиіональний аграрний університет, м. Суми, Украӥна
}

Всім відомо, щ⿻ тест-культури використовують для контролю і якості ростових властивостей живильних середовищ, для перевірки активності антисептиків і дезінфектантів, а також для оцінки адекватності проведення методик чутливості досліджуваних мікроорганізмів до нових антибактеріальних препаратів, які нині виробляються стрімкими темпами у зв'язку з розвитком антибіотикорезистентності мікроорганізмів до більшості застосовуваних активно діючих речовин нових препаратів. І саме розуміння того, щуо більшість антибіотиків є клінічно марними в лікуванні інфекційних хвороб через довготривале їхнє застосування з хіміотерапевтичною метою - велика проблема не тільки в Украӥні а й в усьому світі. У нашій статті наведено результати досліджень чутливості музейних итамів мікроорганізмів, а саме: Escherichia coli ATCC 25922 (F-50), Pseudomonas aеruginosa 
ATCC 2853 (F), Proteus vulgaris HX 19 № 222, Staphylococcus aureus ATCC 25923, Enterobacter aerogenes 10006, Enterococcus faecalis АТСС 19433 до антибактеріального препарату “Сарофлокс". Нами встановлено, що “Сарофлокс" пригнічував ріст всіх дослідних тест-культур в різному ступені розведення. Використовуючи при иьому різну концентрачію антибіотика $(2,5$ м2, 1.25 мг, 0,625 мг, 0,3125 мг, 0,1562/200мкл) було встановлено шо всі досліджувані тест-культури проявляли високу чутливість до препарату “Сарофлокс" зона затримки яких становила здебільшого від 38,0 1 1,0 до 20,0 \pm 1,0 мм. В результаті отриманих досліджень можсна сказати, що новий антибактеріальний препарат "Сарофлокс" володіє бактерицидними властивостями до більшості культур, які спричиняють бактеріальні захворювання різних видів тварин і птиці, щяо лише підтверджує його ефективність до грамнегативних мікроорганізмів (Enterobacter spp., Pseudomonas spp., Streptococcus spp., Staphylococcus aureus E. coli ma iн.), в тому числі резистентних до бета-лактамних антибіотиків, тетрациклінів, макролідів та аміноглікозидів.

Ключові слова: чутливість, мікроорганізми, тест-культури, бактерицидність, препарат “Сарофлокс”.

\section{Вступ}

Проблема антибіотикорезистентності мікроорганізмів визнана глобальною і в даний час належить до одного зі стратегічних завдань у всьому світі щодо стримування розвитку і розповсюдження антибіотикорезистентних мікроорганізмів. Але швидкість, 3 якою формується і розповсюджується стійкість мікроорганізмів до антибактеріальних препаратів, вражає. Препарати, які були ефективними донині, втрачають свої властивості, тому використання їх вимушено обмежується (Levy, 1997; Homeniuk et al., 2010). I це обумовило появу нових форм бактерій, вірусів, мікоплазм, хламідій, що радикально замінило мікрофлору у тварин, птиці, навіть людини на агресивну 3 утворенням бактерій-мутантів (Hunter \& Hart, 1993; Jacobs-Rejstma et al., 1994). І.П. Павлов, російський вчений, лауреат Нобелівської премії сказав: “Діючи на мікроорганізми, не слід забувати, що вони мають також свої інтереси". Антибіотикорезистентність сьогодні виходить за рамки суто медичної проблеми, має величезне соціально-економічне значення й у розвинених країнах розглядається як загроза національної безпеки. Тому для кожної країни постає питання вирішення проблеми антибіотикорезистентності, не залежно від того, чи це створення спеціальних комітетів (в Англії є спеціальний комітет, який займається проблемою антибіотиків), чи розголос проблеми в сучасних мас-медіа, та з огляду на це все лабораторні дослідження з метою визначення чутливості мікроорганізмів - збудників інфекційних хвороб до АБП набуває все важливішого значення (Chemych et al., 2012; Daineka, 2013; Klishheva, 2016). Рішення проблеми антибіотикорезістентності складається 3 трьох скла- дових - пошук нових антибіотиків, комбінація антибактеріальних препаратів та ротація препаратів в господарствах. Успіх терапевтичного ефекту залежить від застосування препаратів нових класів та мікробіологічного обгрунтування вибору антибактеріального препарату (Ministerstvo okhorony zdorovia Ukrainy. Nakaz №167 vid 05.04.2007).

Мета $i$ завдання дослідження: визначення чутливості депонованих тест-штамів мікроорганізмів до антибактеріального препарату “Сарофлокс”.

\section{Матеріал і методи досліджень}

Дослідження проводилися на базі Державного науково-контрольного інституту біотехнології і штамів мікроорганізмів. 3 метою вивчення бактерицидних властивостей антибактеріального препарату “Сарофлокс" використовували депоновані тест-штами мікроорганізмів, а саме Escherichia coli ATCC 25922 (F-50), Pseudomonas aeruginosa ATCC 2853 (F), Proteus vulgaris HX 19 № 222, Staphylococcus aureus ATCC 25923, Enterobacter aerogenes 10006, Enterococcus faecalis ATCC 19433. Чутливість мікроорганізмів до препарату "Сарофлокс" визначали методом серійних розведень в бульйоні та методом серійних розведень в агарі згідно з МУК 4.2.1890-04 (Opredelenie chuvstvitel'nosti mikroorganizmov..., 2004).

Метод серійних розведень в агарі відрізняється лише тим що, інокуляцію препарату "Сарофлокс" здійснювали у лунки на агарі в кількості 200 мкл 3 концентрацією антибактеріального препарату в кожному наступному розведенні в 2 рази нижче, ніж в попередній (рис. 1, 2).
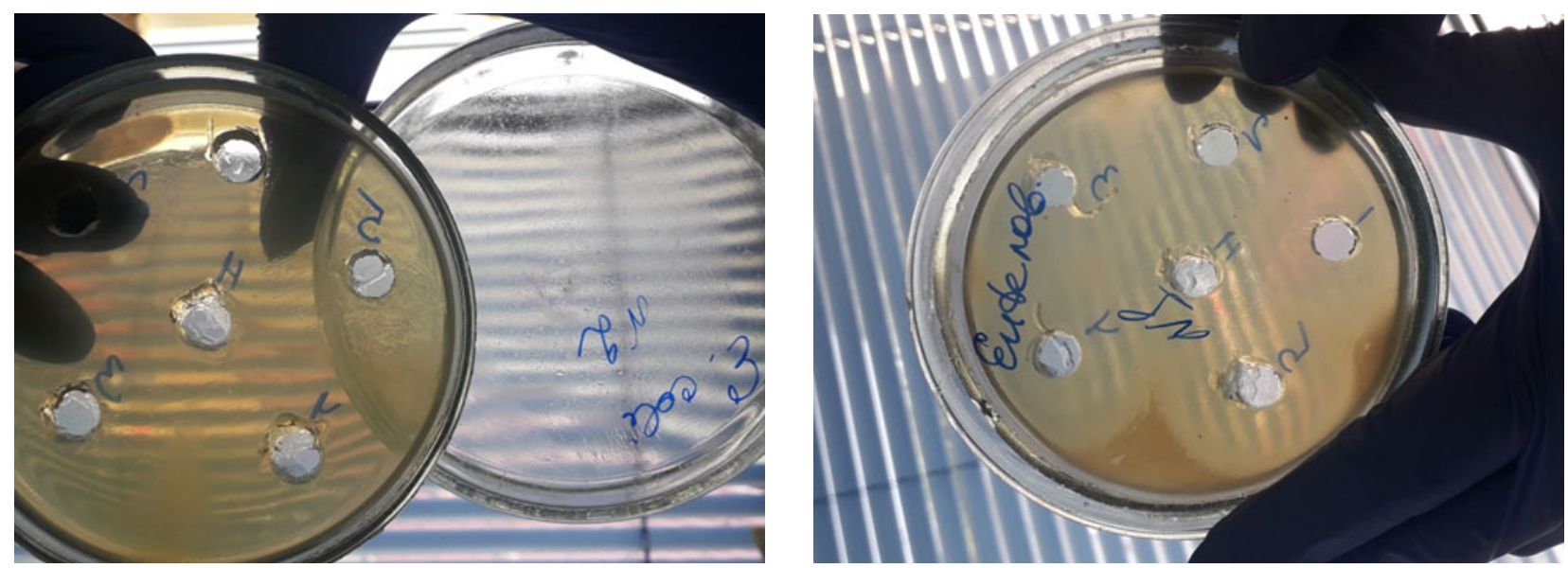

Рис.1, 2. Визначення чутливості E. coli АТCC 25922 (F-50) до препарату “Сарофлокс” 
Робочий розчин “Сарофлоксу” готували із розрахунку 100 г препарату на 200 мл дистильованої води, що становить, згідно з листівкою-вкладкою на препарат, 50 мг “Сарофлоксу” в 1 см$^{3}$ дистильованої води.

\section{Результати та їх обговорення}

При дослідженні чутливості музейних штамів мікроорганізмів до препарату “Сарофлокс" методом серійних розведень встановлено, що препарат пригнічував ріст усіх штамів мікроорганізмів, але в різному ступені (табл. 1).

Як видно з таблиці 1, культура Escherichia coli ATCC 25922 (F-50) виявляла високу чутливість до препарату "Сарофлокс" незалежно від ступеня розведення та власне його концентрації, зона затримки становила від $(38,0 \pm 1,0)$ мм до $(24,0 \pm 1,0)$ мм. Про- довжуючи аналіз індивідуальної чутливості дослідних тест-культур, нами було виявлено, що штами Staphylococcus aureus ATCC 25923, Pseudomonas aeruginosa ATCC 2853 (F) були чутливим до препарату у таких концентраціях: 2,5 мг, 1,25 мг, 0,625 мг, 0,3125 мг, 0,1562/200 мкл зона затримки - від $(32,0 \pm 1,0)$ до $(20,0 \pm 1,0)$ мм та від $(28,0 \pm 1,0)$ до $(20,0 \pm 1,0)$ мм відповідно. Аналогічні інгібуючі властивості препарат “Сарофлокс" проявляв до інших двох досліджуваних культур Proteus vulgaris HX 19 № 222 та Enterobacter aerogenes 10006 зона затримки яких - від $(30,0 \pm 1,0)$ до $(22,0 \pm 1,0)$ та від $(26,0 \pm 1,0)$ до $20,0 \pm 1,0)$ на відміну від культури Enterococcus faecalis ATCC 19433 яка була чутлива тільки до трьох концентрацій (2,5 мг, 1,25 мг, 0,625 мг/200 мкл) препарату "Сарофлокс".

\section{Таблиця 1}

Результати вивчення чутливості депонованих тест-культур мікроорганізмів до антибактеріального засобу "Сарофлокс"

\begin{tabular}{|c|c|c|c|c|c|c|}
\hline \multirow[t]{3}{*}{ Випробний мікроорганізм } & \multicolumn{6}{|c|}{$\begin{array}{c}\text { Діаметр зони затримки росту, мм } \\
\text { Концентрація препарату “Сарофлокс” в кожному подальшому розведенні } \\
\text { в } 2 \text { рази нижча, ніж в попередньому }\end{array}$} \\
\hline & Без розведення & 1 & 2 & 3 & 4 & 5 \\
\hline & & $2,5 \mathrm{M \Gamma}$ & $1.25 \mathrm{M \Gamma}$ & 0,625 мг & 0,3125 мг & 0,1562 \\
\hline Escherichia coli ATCC $25922(F-50)$ & $(40,0 \pm 1,0)$ & $(38,0 \pm 1,0)$ & $(34,0 \pm 1,0)$ & $(32,0 \pm 1,0)$ & $(30,0 \pm 1,0)$ & $(24,0 \pm 1,0)$ \\
\hline Pseudomonas aeruginosa ATCC $2853(F)$ & $(30,0 \pm 1,0)$ & $(28,0 \pm 1,0)$ & $(26,0 \pm 1,0)$ & $(24,0 \pm 1,0)$ & $(20,0 \pm 1,0)$ & $(20,0 \pm 1,0)$ \\
\hline Proteus vulgaris $H X 19$ № 222 & $(32,0 \pm 1,0)$ & $(30,0 \pm 1,0)$ & $(28,0 \pm 1,0)$ & $(26,0 \pm 1,0)$ & $(24,0 \pm 1,0)$ & $(22,0 \pm 1,0)$ \\
\hline Staphylococc & $(34,0 \pm 1,0)$ & $(32,0 \pm 1,0)$ & $(30$ & ,0) & $(24,0$ & $(20,0$ \\
\hline Enterobacter a & $(28,0 \pm 1,0)$ & $(26,0 \pm 1,0)$ & $(24,0 \pm 1,0)$ & $(22,0 \pm 1,0)$ & $(21,0 \pm 1,0)$ & $(20,0 \pm 1,0)$ \\
\hline Enterococcus faecalis ATCC 19433 & $(20,0 \pm 1,0)$ & $(18,0 \pm 1,0)$ & $(16,0 \pm 1,0)$ & $(14,0 \pm 1,0)$ & $(12,0 \pm 1,0)$ & $(10,0 \pm 1,0)$ \\
\hline
\end{tabular}

\section{Висновки}

Доведено бактерицидну активність препарату “Сарофлокс" до депонованих штамів тест-культур Escherichia coli ATCC 25922 (F-50), Staphylococcus aureus ATCC 25923, Pseudomonas aeruginosa ATCC 2853 (F), Proteus vulgaris HX 19 № 222, Enterobacter aerogenes 10006 ma Enterococcus faecalis ATCC.

Перспективи досліджень. Визначення бактерицидних властивостей препарату “Сарофлокс" до мікроорганізмів ізольованих в птахівничих господарствах України.

\section{References}

Chemych, M.D., Kozko, V.M., ta in. (2012). Antybiotykorezystentnist ta shliakhy yii podolannia: Materialy Vse-ukrainskoi naukovo-praktychnoi konferentsii i plenumu "Asotsiatsii infektsionistiv Sumshchyny" Sumy, SUMDU, 104 (in Ukrainian).

Daineka, S. (2013). Antybiotykorezystentnist. Bukovynskyi derzhavnyi medychnyi universytet [Elektronnyi resurs]: https://www.bsmu.edu.ua/uk/news/digest/1131antibiotikorezistentnist (in Ukrainian).

Golovko, A.N., Ushkalov, V.A., Stegnij, B.T ta in. (2007). Mikrobiologicheskie i virusologicheskie me- tody issledovanij $\mathrm{v}$ veterinarnoj medicine. Harkiv: NTMT (in Russian).

Homeniuk, M.I., Denysov, O.S., \& Feshchenko, Yu.I. (2010). Antybiotykorezystentnist mikroorhanizmiv. Stan problemy ta shliakhy vyrishennia. Ukrainskyi khimioterapevtychnyi zhurnal, 1-2(23), 4-10. https:/www.uf.ua/wp-content/uploads/2015/12/ 8337fd820b2a2669fd8c4fb3b8549041.pdf (in Ukrainian).

Hunter, J.E., \& Hart, C.A (1993). Human isolates of apramisin resistant E. coli which contain thegenes for the AAC IV enzyme. Epidem. Infect., 110(2), 253259. doi: 10.1017/S0950268800068175.

Jacobs-Rejstma, W.F., Kan, C.A., \& Bolder, N.M. (1994). The induetion of guinoloxe resistant Campylobacterbacteria in broilers bu quinolone treatment Lett. Appl. Microbiol., 19(4), 228-231. doi: 10.1111/j.1472765X.1994.tb00950.x.

Klishheva, Zh.E. (2016). Chuvstvitel'nost' vozbuditelej bakterial'nyh boleznej pticy $\mathrm{k}$ antibakterial'nym preparatam. Mat. Mezhd. nauchn.-prakt. konf. "Prioritety veterinarnoj nauki i innovacionnyj opyt", posvjashhennoj 115 letiju obrazovanija Azerbajdzhanskogo VNII, 14-15 dekabrja 2016. VNII. g. Baku, 287-291 (in Russian). 
Levy, S.B. (1997). Antibiotic resistance: an ecological imbalance. Ciba Found Symp., 207, 1-9. doi: 10.1002/9780470515358.ch1.

Ministerstvo okhorony zdorovia Ukrainy. Nakaz №167 vid 05.04.2007. Metodychni vkazivky "Vyznachennia chutlyvosti mikroorhanizmiv do antybakterialnykh preparativ". https://zakon.rada.gov.ua/rada/show/ v0167282-07 (in Ukrainian).

Opredelenie chuvstvitel'nosti mikroorganizmov k antibakterial'nym preparatam (2004). Metodicheskie ukazanija. M.: Federal'nyj centr gossanjepidnadzora minzdrava Rossii (in Russian). 